Anadolu Üniversitesi Bilim ve Teknoloji Dergisi A- Uygulamalı Bilimler ve Mühendislik Anadolu University Journal of Science and Technology A- Applied Sciences and Engineering

2016 - Volume: 17 Number: 3

Page: 484 - 496

DOI: $10.18038 / \mathrm{btda} .84861$

Received: 15 January 2016

Revised: 30 June 2016

Accepted: 23 August 2016

\title{
DETERMINATION OF THE IMPACTS OF LAND USE CHANGE ON WATER BASIN USING REMOTE SENSING AND GEOGRAPHICAL INFORMATION SYSTEM
}

\author{
Abdurrahman GEYMEN* \\ Department of Geomatics Engineering, Faculty of Engineering, Erciyes University, Kayseri, Turkey
}

\begin{abstract}
The population in Istanbul has been increasing as a result of mass immigration. An urbanization process continues and it causes serious increases in urban areas while decreasing the amount of natural environment. This uncontrolled and illegal urbanization accompanied by insufficient infrastructure has caused degradation of cropland and forested areas in the metropolitan area, especially in water basin area. The watershed basins inside the metropolitan area have accelerated the land-cover changes, which have negative impacts on water quality of the basins. The Terkos water basin, one of the seven water basins of Istanbul providing drinking water, was selected as a study area. In order to understand the effect of the land use change of the water basin in Istanbul Metropolitan Area, we used the three Landsat satellite images of the years 1995, 2005 and 2010. The study mainly focuses on the acquisition and analysis of Landsat TM satellite images reflecting the significant land-cover changes between the years of 1995 and 2010. The findings show that the settlement areas emerged mainly on the protection zones of the Terkos basin and created serious environmental problems. The land use change will effect precipitation change on direct surface runoff in water basin.
\end{abstract}

Keywords: Geographical information system; Remote sensing; Urbanization; Water basin

\section{INTRODUCTION}

Land use changes have potentially large impacts on water resources [1]. Rapid socio-economic development drives land use changes, which include changes of land use classes, e.g., conversion of cropland to urban area due to urbanization, as well as changes within classes such as a change of crops or crop rotations [2-3]. Particularly in regions where water availability is limited, land use changes could result in an increase of water scarcity and thus contribute to a deterioration of living conditions [3]. In order to assess land use changes, Landsat satellite images provide valuable spatially distributed information. Historic multispectral satellite images can be used to produce past land use classifications [4-5]. These classifications are superior to commonly used freely available, global data sets [6], as they provide a higher spatial resolution $(30 \mathrm{~m})$ and often have a higher level of detail with regard to the number of distinguished classes. Each land use classification is representative of the date of the satellite image [7]. Investigations of the effects of past land use changes on water availability have been carried out in many regional studies worldwide [4, 8, 9,10, 11]. Furthermore, impacts of land use scenarios on the water resources have been analyzed in many other regional studies $[12,13,14,15,16$, $17,18,19]$.

[20] and [21] show the linear growth of city along the proposed third bridge and draw attention to the northward growths and incursions into the surface water resources basins. [22] analyzes the land use changes for İkitelli area of Istanbul by evaluating remote sensing images obtained from Landsat TM (1984 and 1992). [23] study using the IKONOS XS+Pan (2002), they detect rapid spatial changes between the years 1984 and 1998, which are mainly the loss of agricultural lands for urban uses, due to migration and high natural population growth rate. [24] on a temporal assessment of land-cover changes of the Beykoz District in Istanbul using Landsat 5 TM images (1984, 1992, and 2001) show that the rapid urbanization within the past two decades has caused degradation of forests and barren

*Corresponding Author: ageymen@erciyes.edu.tr 
lands in the province. [25] take a more quantitative approach to determine urban growth on the European side of Istanbul by using Landsat 5 TM images for 1987, 1992, 1997 and 2001. [26] studies Land-use/land-cover characteristics of Terkos Water Resource Basin via Landsat TM and Spot P (1984 and 1992) images, and concludes that the unplanned development in Terkos Basin, is the result of the creation of the Trans European Motorway (TEM) and the second Bosporus Bridge. [27] study all of the basins in the Province of Istanbul by using Landsat GeoCover LC-1990 and 2000 satellite images, and conclude that in addition to the impacts of the capital improvement projects.

Istanbul is stretched in both the eastern and western directions from the southern shores of the Bosporus. After the construction of the Trans European Motorway (TEM), the second Bosporus Bridge and advised third bridge, the urban built-up area stretches out to the north, where surface water resource basins lie. Both organized industrial districts are served by the TEM cutting through both basins and surrounded by settlements providing employees to these districts. On the European side, the industrial districts are scattered around the water resources basins, and are served by the major transportation lines, E-5, TEM and advised third bridge their connections. One of those industrial districts, named "İkitelli Industrial District," is near the Terkos Basin, which is the most negatively affected basin in terms of the extent of surrounding settlements. Regarding the data from Landsat TM 1995 and 2010 for each basin, the largest share of cropland and frosted areas as a percentage of the total basin area, occurs in Terkos Basin. These results showed that during years 1995-2010, the buildup areas happened mainly on the protection zones of the Terkos basin and created serious environmental problems. Undesired growth in the Terkos basins, agriculture and forested areas provide the following prevention strategies: (i) making the residents in this area conscious of the need to protect natural resources, (ii) focusing on planning and zoning tools, (iii) monitoring the changes in natural resources, taking measures to protect natural resources, (iv) using geographical information system and remote sensing techniques effectively, and (v) enacting the required regulations. Any large capital improvement project affecting water resource basins in Istanbul, such as construction of a third bridge on the Bosporus and third airport, must be considered within a comprehensive approach that addresses the points mentioned above.

\section{MATERIAL AND METHOD}

As outlined in Figure 1, we use remote sensing and GIS to analyze effects of the land use change on the hydrologic structure of the Terkos Basin in Istanbul Metropolitan Area. The nearest neighbor resampling method was used to avoid altering the original pixel values of the image data. Geometric correction was done by satellite images belonging to 1995, 2005 and 2010. In classification, a supervised image classification Maximum likelihood method is used. The overall accuracy and a KAPPA analysis were used to perform classification accuracy assessment based on error matrix analysis. Then after which the classified raster images are converted to vector maps and thematic land use maps has been obtained. The geological and agricultural land use capability maps are overlayed with the created land use maps. Finally, the resulting GIS database is used as the input parameter for SCS Method which was developed by the Soil Conservation Service for the calculation of curve numbers. 
Geymen / Anadolu Univ. J. of Sci. and Technology - A - Appl. Sci. and Eng. 17 (3) - 2016

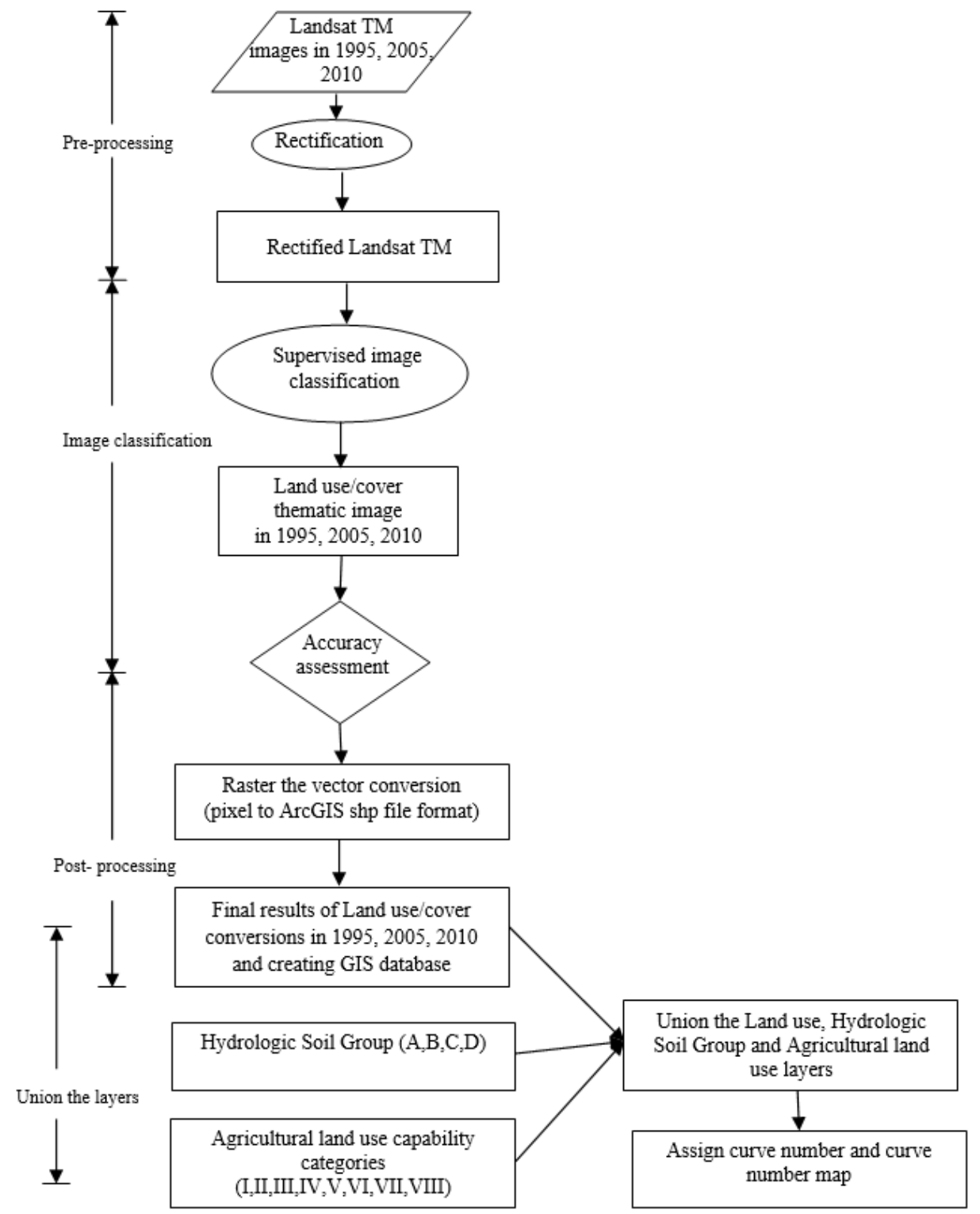

Figure 1. The methodology of this study

\subsection{Study Area}

Terkos Basin, one of the dams providing drinking water to Istanbul, was selected as a study area in Figure 2. The Terkos Dam water basin area is located on the European side, approximately $50 \mathrm{~km}$ away from Istanbul's city centre and has recently been connected to the city through the Transit European Motorway (TEM). It has a reservoir area of $32 \mathrm{~km}^{2}$ and a total drainage area of $735 \mathrm{~km}^{2}$. The basin is separated into conservation bands according to rules of Istanbul Water Board Authority [26]. 


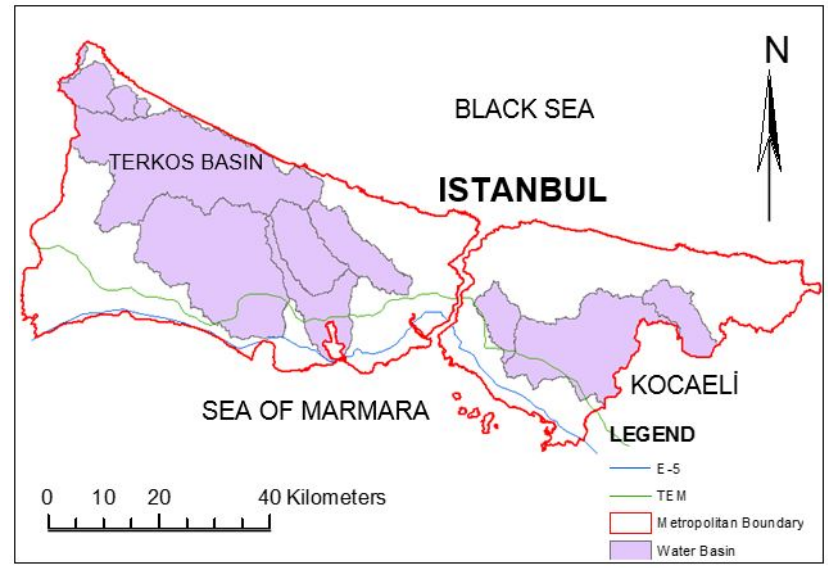

Figure 2. Location of the study area

\subsection{Data Sets}

To calculate the value of Curve Number $(\mathrm{CN})$, geology, agricultural land use capability and land use maps were used. On the other hand, for the Terkos Basin, the scale of geology map is $1 / 5000$, and for the agricultural land use capability maps, the used scale is $1 / 25000$ for Istanbul's surface water resources basins. The geology maps and agricultural land use capability maps are obtained from the Geographic Information Systems Department of the General Directorate of Agricultural Reform, Republic of Turkey Ministry of Food, Agriculture and Livestock.

1995, 2005 and 2010 Landsat TM satellite images and base maps are used to identify the land use patterns of surface water resources basins. Table 1 shows characteristics of the satellite data used for land use change mapping in the study area.

Table 1. Characteristics of the satellite data used for land use change mapping in the study area

\begin{tabular}{cccccc}
\hline Date & $\begin{array}{c}\text { Type of } \\
\text { imagery }\end{array}$ & $\begin{array}{c}\text { Path/ } \\
\text { Row }\end{array}$ & $\begin{array}{c}\text { Nominal spatial } \\
\text { resolution(m) }\end{array}$ & $\begin{array}{c}\text { Sun } \\
\text { elevation }\left({ }^{\mathbf{o}}\right)\end{array}$ & $\begin{array}{c}\text { Sun azimuth } \\
(\mathbf{(})\end{array}$ \\
\hline June 1995 & TM+ & $175 / 31$ & 30 & 56.40 & 137.90 \\
June 2005 & TM+ & $175 / 31$ & 30 & 55.10 & 138.50 \\
July 2010 & ETM + & $175 / 31$ & 30 & 55.40 & 138.35 \\
\hline
\end{tabular}

Also, a 2010 Ikonos satellite image, standard 1/25000 scale topographic maps, environmental physical plan scaled 1/100000, various thematic maps and ground truth studies are all used as base maps for the province of Istanbul in this study. The satellite images and base maps are obtained from the United States Geological Survey (USGS).

\subsection{Method}

The satellite images that were acquired 1995, 2005 and 2010 were processed by following three processes namely: pre-processing, classification and post classification as shown in the Figure 1. In classification, a supervised image classification Maximum likelihood method is used. First, Landsat satellite images were rectified to the UTM coordinate system. Next, Erdas Imagine 9.1 and ArcGIS 10 were selected for various analyses and image classification [28-29]. The classified images were further smoothed with a majority filter with a $3 \times 3$ kernel to reduce the number of misclassified pixels [28]. These classification categories in the study area are water, cropland, settlement, forest, and barren area to be determined as a seven classification. 
The nearest neighbor resampling method was used to avoid altering the original pixel values of the image data. Thus, the image of 1995 was geometrically corrected using 52 control points. The root mean square error (RMSE) was 0.50 pixels. Geometric correction of the other two images was done by image to image rectification strategy with reference to 1995 image. 2005 image of the study area was geometrically corrected using 33 control points and RMSE was 0.54 pixels. 2010 image were geometrically corrected using 38 control points and RMSE was 0.57 pixels.

The Kappa statistic and overall accuracy are used to measure the agreement between two sets of categorizations of a dataset while correcting for chance agreements between the categories. Jenness's Kappa analysis in ArcView 3.x extension was used to estimate the sample size required to achieve a confidence level and precision for statistical analysis [30]. The error matrix is produced after calculating the minimum sample size. Table 2 shows overall classification accuracy and kappa results for Terkos Basin. Our results show that kappa and overall accuracy are greater than $70 \%$. Kappa values were characterized as excellent over $0.75,0.40$ to 0.75 as fair to good, and below 0.40 as poor [31]. The high overall and high Kappa coefficient suggests a good relationship between the classified image and the reference data $[7,31]$.

Table 2. Results of classification accuracy for Terkos Basin

\begin{tabular}{|l|c|c|}
\hline Images & $\begin{array}{c}\text { Overall classification } \\
(\mathbf{\% )}\end{array}$ & Kappa (\%) \\
\hline 1995 Landsat TM & 89 & 82 \\
2005 Landsat TM & 86 & 83 \\
2010 Landsat TM & 91 & 86 \\
\hline
\end{tabular}

Then after which the classified raster images are converted to vector maps and thematic land use maps has been obtained (Figure 3-5). GIS database is created by eliminating topological errors in the land use data obtained. In Figure 6 and 7, the geological and agricultural land use capability (LUC) maps are overlayed with the created land use maps (Figure 8). In Figure 6, these four groups are named by letters from A to D in geological maps. Among these groups, group A has low runoff potential while group D has high runoff potential. In Figure 7, agriculture map has the values ranging between LUC I and LUC VIII depending on whether the land is flat or steep. The value 'I' indicates lands with a flat inclination while the value 'VIII' refers to steep lands, with the inclination values increasing gradually between them. Finally, the resulting GIS database is used as the input parameter for SCS Method which was developed by the Soil Conservation Service for the calculation of curve numbers.

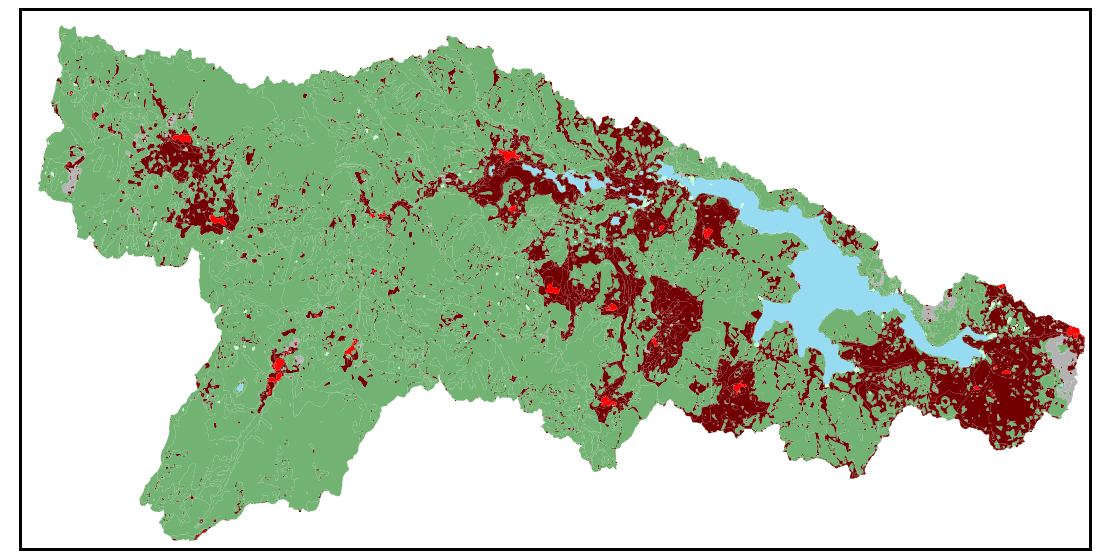

Figure 3. 1995 Terkos watershed remote sensing land use map 
Geymen / Anadolu Univ. J. of Sci. and Technology - A - Appl. Sci. and Eng. 17 (3) - 2016

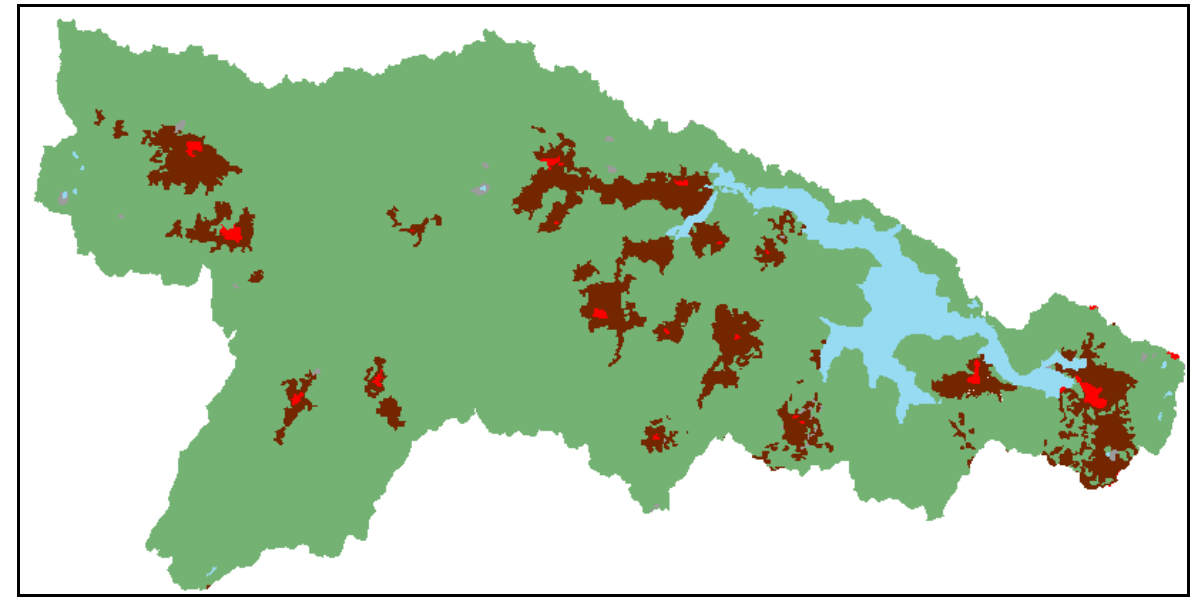

Figure 4. 2005 Terkos watershed remote sensing land use map

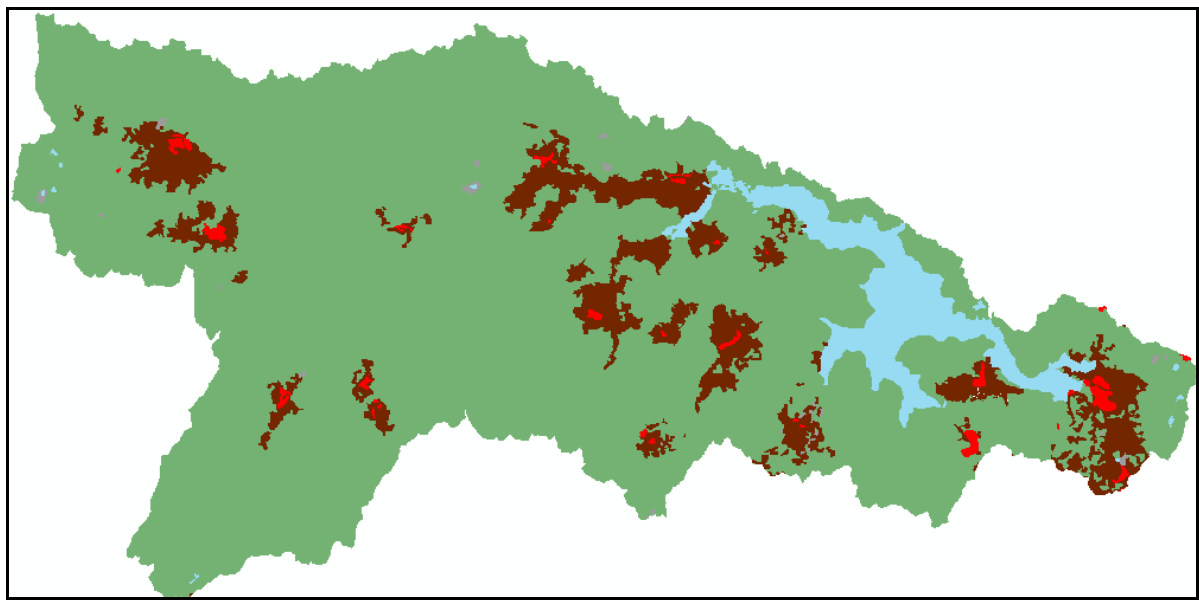

Figure 5. 2010 Terkos watershed remote sensing land use map

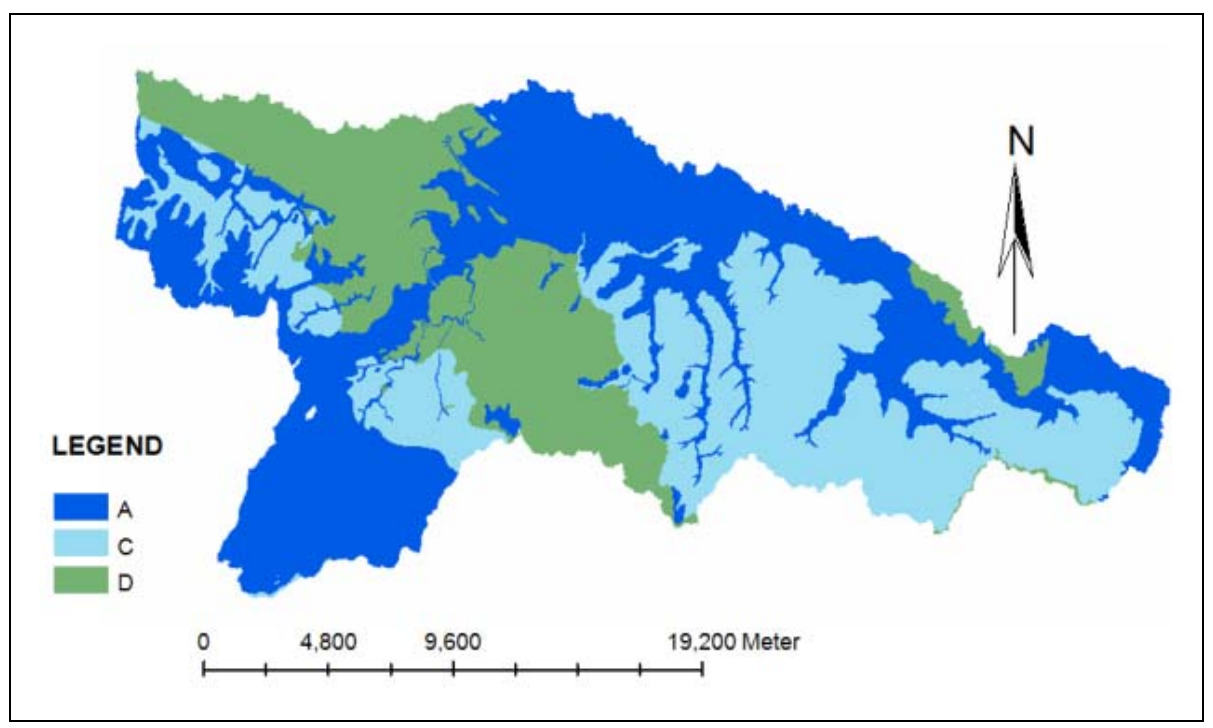

Figure 6. Terkos watershed hydrologic earth classification map 
Geymen / Anadolu Univ. J. of Sci. and Technology - A - Appl. Sci. and Eng. 17 (3) - 2016

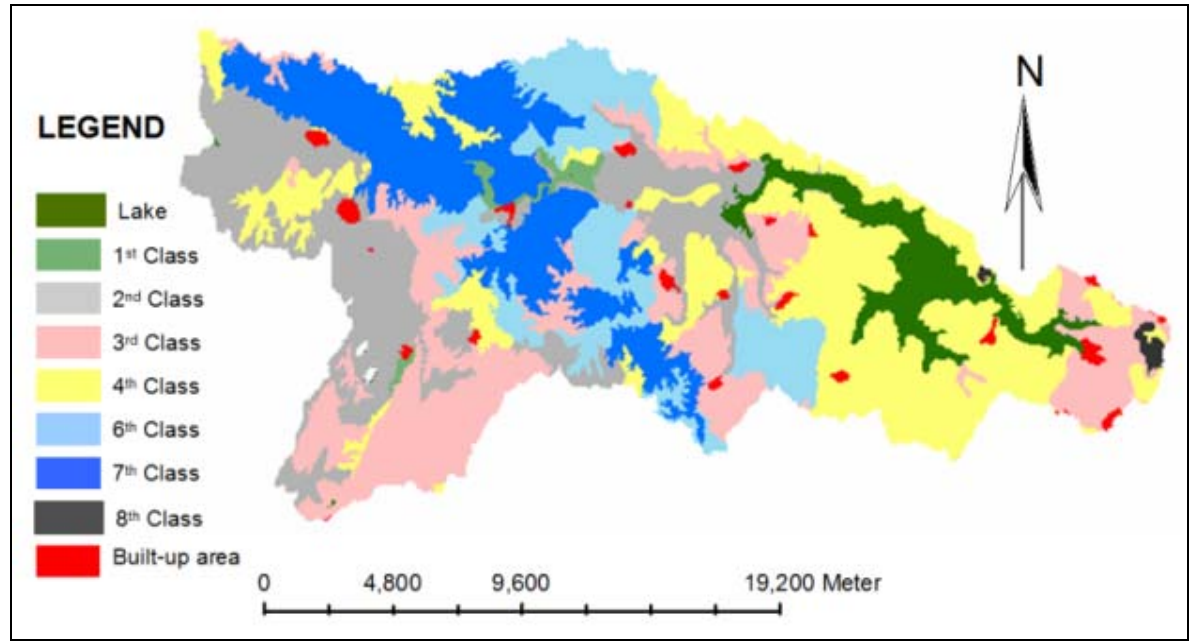

Figure 7. Terkos watershed agricultural land use capability class map

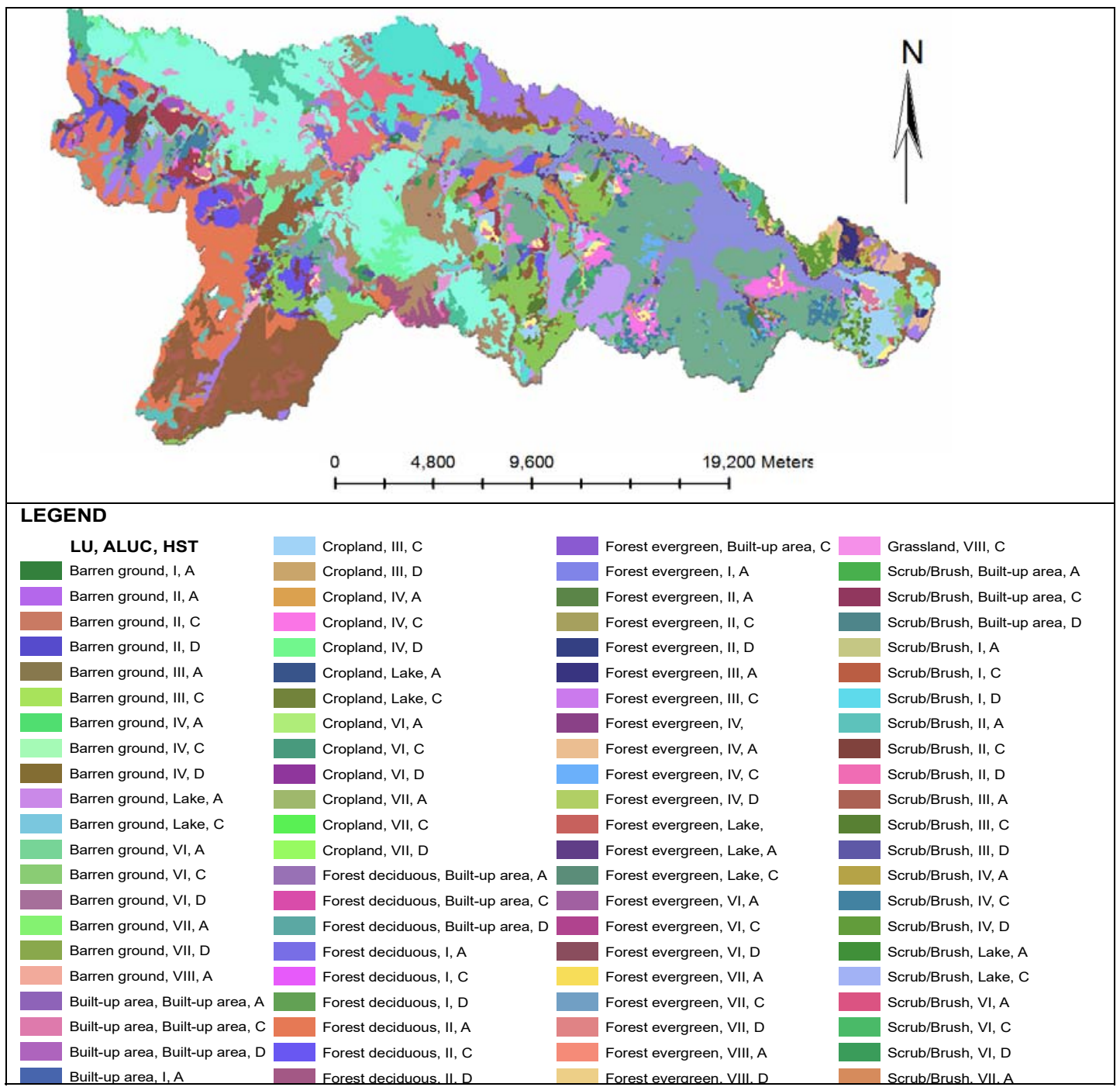

Figure 8. Terkos watershed curve number determination information categories map 


\subsection{Used CN}

This section is made up of two subsections: i) Surface database reclassification process and overlay operations, and ii) $\mathrm{CN}$ assignment to the created polygons.

Classification Methodology: Curve numbers (CN) are derived from the integrated evaluation of various natural and built environment database maps. These maps are G: geology, T: agricultural land use capability, L: land use. In the process of evaluation, Geographic Information System (GIS) is the environment that easily handles extensive and various sources of digital maps and associated data bases. During the overlay operations, these three map based databases are used to create a new set of polygon database containing geology, agricultural land use capability, and land use information (G: $\mathrm{g}_{1} \rightarrow \mathrm{g}_{\mathrm{R}}, \mathrm{T}: \mathrm{t}_{1} \rightarrow \mathrm{t}_{\mathrm{Z}}, \mathrm{L}: \mathrm{l}_{1} \rightarrow 1_{\mathrm{K}}$ ) to be able to compute a unique $\mathrm{CN}$ for each water resources basin. For each basin, the created polygon data base $\left(\mathrm{X}: \mathrm{x}_{1} \rightarrow \mathrm{x}_{\mathrm{N}}\right)$ contains various polygons that have associated curve numbers (Table 3). These $\mathrm{CNs}$ later are aggregated to a single average $\mathrm{CN}$ for the studied basin.

Table 3. Overlay operation and curve number $(\mathrm{CN})$ assignment

\begin{tabular}{|c|c|c||c||c|}
\hline \multicolumn{3}{|c||}{ Inputs } & Overlay Output & CN Assignment \\
\hline \hline $\begin{array}{c}\mathbf{G} \\
\mathrm{g}_{1} \rightarrow \mathrm{g}_{\mathrm{R}}\end{array}$ & $\begin{array}{c}\mathbf{T} \\
\mathrm{t}_{\mathrm{z}} \rightarrow \mathrm{t}_{\mathrm{Z}}\end{array}$ & $\begin{array}{c}\mathbf{L} \\
\mathrm{l}_{1} \rightarrow \mathrm{l}_{\mathrm{K}}\end{array}$ & $\begin{array}{c}\mathbf{X} \\
\mathrm{x}_{1} \rightarrow \mathrm{x}_{\mathrm{N}}\end{array}$ & $\begin{array}{c}\mathbf{C N} \\
\mathrm{c}_{\mathrm{X} 1} \rightarrow \mathrm{cn}_{\mathrm{XN}}\end{array}$ \\
\hline $\mathrm{g}_{1}$ & $\mathrm{t}_{1}$ & $\mathrm{l}_{1}$ & $\mathrm{x}_{1}$ & $\mathrm{cn}_{\mathrm{X} 1}$ \\
\hline $\mathrm{g}_{\mathrm{r}}$ & $\mathrm{t}_{\mathrm{z}}$ & $\mathrm{l}_{\mathrm{k}}$ & $\mathrm{x}_{\mathrm{n}}$ & $\mathrm{cn_{ \textrm {Xn } }}$ \\
\hline$\ldots$ & $\ldots$ & $\ldots$ & $\ldots$ &.. \\
\hline $\mathrm{g}_{\mathrm{R}}$ & $\mathrm{t}_{\mathrm{Z}}$ & $\mathrm{l}_{\mathrm{K}}$ & $\mathrm{x}_{\mathrm{N}}$ & $\mathrm{cn}_{\mathrm{XN}}$ \\
\hline
\end{tabular}

Table 4. Hydrologic Soil Type attribution to the codes of top layer geological formations

\begin{tabular}{|c|c|c|c|c|c|c|c|c|c|c|c|c|c|}
\hline \multicolumn{14}{|c|}{ Province of Istanbul (Geology Map - Scale: 1 / 5 000) } \\
\hline$\overline{\mathbf{A}}$ & $\mathrm{Pl} \mathrm{Qa}$ & Qal & Qyd & Tda & Tkry & & & & & & & & \\
\hline \multirow[t]{2}{*}{ B } & PTRk & Ps & $\mathrm{Ct}$ & Tşa & Qym & Qs & TQd & Tçb & Tdsi & Töm & Tös & Oak & $\mathrm{Tp}$ \\
\hline & Tkcb & DCd & DCdt & Dcda & TRgb & & & & & & & & \\
\hline \multirow[t]{2}{*}{$\mathbf{C}$} & Ctc & Ctkç & Ksk & Ksg & Ks & Ktay & Ktaa & $\mathrm{KTa}$ & Tşi & Tçç & Tds & OSy & OSyș \\
\hline & $\begin{array}{l}\text { Opkb } \\
\text { DCdy }\end{array}$ & $\begin{array}{l}\text { Opks } \\
\text { TRgt }\end{array}$ & $\begin{array}{l}\text { Tkcş } \\
\text { Trgde }\end{array}$ & $\begin{array}{l}\text { Tks } \\
\text { TRgdd }\end{array}$ & Ty & Tkrv & PzTRş & Dkk & Tök & SDp & SDpm & SDps & SDpsg \\
\hline \multirow[t]{2}{*}{ D } & $\mathrm{Ctk}$ & PzTRç & Qkş & Cta & Ksb & $\mathrm{Kç}$ & $\mathrm{Ts}$ & Qkm & Tçg & Tdç & Tdss & Tdg & Tök \\
\hline & $\begin{array}{l}\text { OSyg } \\
\text { Trşbk }\end{array}$ & $\begin{array}{l}\text { OSyu } \\
\text { TRgd }\end{array}$ & $\begin{array}{l}\text { Oa } \\
\text { TRgdg }\end{array}$ & Oab & Opk & Opkc & Tkcy & Tkk & PzTRk & PzTRç & DCdb & $\mathrm{Dk}$ & SDpd \\
\hline \multicolumn{14}{|c|}{ Reference Soil Types (Şen 2009) } \\
\hline $\begin{array}{l}\mathbf{A} \\
\mathbf{B} \\
\text { C } \\
\text { D }\end{array}$ & $\begin{array}{l}\text { Lowest flow } \\
\text { Mid-low flo } \\
\text { Mid_high flo } \\
\text { Highest flow }\end{array}$ & $\begin{array}{l}\text { iency: De } \\
\text { iciencies: } \\
\text { ficient: L } \\
\text { cient: Soil }\end{array}$ & $\begin{array}{l}\text { sand, loes } \\
\text { allow loes } \\
\text { n, shallow } \\
\text { at swell }\end{array}$ & $\begin{array}{l}\text { ilts and a } \\
\text { andy/plar } \\
\text { aded loan } \\
\text { n get wet }\end{array}$ & $\begin{array}{l}\text { egate } \\
\text { soil } \\
\text { rganica } \\
\text { avy pla }\end{array}$ & $\begin{array}{l}\text { an soils } \\
\text { oams at }\end{array}$ & $\begin{array}{l}\text { usually } \mathrm{h} \\
\text { me salty }\end{array}$ & loame & & & & & \\
\hline
\end{tabular}

Curve Number Assignment to the Created Polygons (X): Curve numbers are attributed to the newly created every polygon separately regarding the principles outlined in Tables 4 and 5 containing Reference Curve Numbers. The reference Table 4 and 5 are adopted from literature [32, 33, 34] for the spatial characteristics of the study areas. Table 4 is prepared to show the hydrologic soil types (G - A, $\mathrm{B}, \mathrm{C}, \mathrm{D})$ of the geological formations, and Table 5 is prepared to lead CN numbers for various HST, land use classes (LU), and agricultural land use capability categories (T). These Reference Curve Numbers succinctly summarize the functional relation between these three sources of information (G: geology, T: agricultural land use capability, L: land-use) and overland flow (surface runoff). Let $x_{n}$ be the newly created polygon, the curve number for that polygon can be presented as $\mathrm{cn}_{\mathrm{xn}}\left(\mathrm{g}_{\mathrm{r}}, \mathrm{t}_{\mathrm{z}}, \mathrm{l}_{\mathrm{k}}\right)$. Regarding the geographic layers of information on polygon $\mathrm{xn}$ (having unique $\mathrm{g}_{\mathrm{r}}, \mathrm{t}_{\mathrm{z}}$, and $\mathrm{l}_{\mathrm{k}}$ values), Table 5 provides a unique corresponding $\mathrm{CN}$ that is used for the computation of entire basin's $\mathrm{CN}$ value. Considering the extent of maps and the number of categorical information in each layer, GIS based overlay operation provides thousands of polygons, and these polygons have various combinations of layer based information. Most of the created polygons have the same layer 
information in different parts of the basins; however, these polygons can be aggregated into single groups with their associated coverage area totals. The total number of these polygon groups can reach maximally to the number of $\mathrm{CN}$ cells in Table 5. In actual cases, the created categories can never reach to the total $\mathrm{CN}$ cell numbers for the study areas. Finally, in order to estimate a unique watershed $\mathrm{CN}$, first areal weights of each polygon group is computed. In this process, let $\mathrm{a}_{\mathrm{xn}}$ be the areal extent of polygon $\mathrm{xn}$, the areal weight of that $\mathrm{a}_{\mathrm{xn}}$ in the basin is computed as $\mathrm{w}_{\mathrm{xn}}=\mathrm{a}_{\mathrm{xn}} / \Sigma_{\mathrm{n}=1}^{\mathrm{N}} \mathrm{a}_{\mathrm{xn}}$. Then, the unique $\mathrm{CN}$ for the watershed is written in equation form as a sum of area weighted curve numbers, $\sum^{\mathrm{N}}{ }_{\mathrm{n}=1} \mathrm{~W}_{\mathrm{xn}} \mathrm{cn} \mathrm{n}_{\mathrm{xn}}$.

Table 5. Reference curve numbers

\begin{tabular}{|c|c|c|c|c|c|c|c|c|c|c|c|}
\hline \multirow{2}{*}{$\begin{array}{l}\text { Satellite } \\
\text { Image Based } \\
\text { Land Use } \\
\text { Categories } \\
\text { (LU - L) }\end{array}$} & \multirow{2}{*}{$\begin{array}{l}\text { Agricultural } \\
\text { Land Use } \\
\text { Capability } \\
\text { (ALUC - T) }\end{array}$} & \multicolumn{4}{|c|}{$\begin{array}{l}\text { Hydrologic Soil } \\
\text { Type (HST - G) }\end{array}$} & \multirow{2}{*}{$\begin{array}{l}\text { Satellite Image } \\
\text { Based Land } \\
\text { Use Categories } \\
(\text { LU - L) }\end{array}$} & \multirow{2}{*}{$\begin{array}{l}\text { Agricultur } \\
\text { al Land } \\
\text { Use } \\
\text { Capability } \\
(\text { ALUC - T) }\end{array}$} & \multicolumn{4}{|c|}{$\begin{array}{l}\text { Hydrologic Soil } \\
\text { Type (HST - G) }\end{array}$} \\
\hline & & $\underline{\mathbf{A}}$ & $\underline{\mathbf{B}}$ & $\underline{\mathrm{C}}$ & $\underline{\mathbf{D}}$ & & & $\underline{\mathbf{A}}$ & $\underline{\mathbf{B}}$ & $\underline{\mathrm{C}}$ & $\underline{\mathbf{D}}$ \\
\hline Scrub/Brush & Empty & 54 & 64 & 69 & 74 & $\begin{array}{l}\text { Forest } \\
\text { deciduous }\end{array}$ & Empty & 54 & 64 & 69 & 74 \\
\hline Scrub/Brush & Lake & 100 & 100 & 100 & 100 & $\begin{array}{l}\text { Forest } \\
\text { deciduous }\end{array}$ & Lake & 100 & 100 & 100 & 100 \\
\hline Scrub/Brush & I & 39 & 49 & 54 & 59 & $\begin{array}{l}\text { Forest } \\
\text { deciduous }\end{array}$ & I & 39 & 49 & 54 & 59 \\
\hline Scrub/Brush & II & 44 & 54 & 59 & 64 & $\begin{array}{l}\text { Forest } \\
\text { deciduous }\end{array}$ & II & 44 & 54 & 59 & 64 \\
\hline Scrub/Brush & III & 49 & 59 & 64 & 69 & $\begin{array}{l}\text { Forest } \\
\text { deciduous }\end{array}$ & III & 49 & 59 & 64 & 69 \\
\hline Scrub/Brush & IV & 54 & 64 & 69 & 74 & $\begin{array}{l}\text { Forest } \\
\text { deciduous }\end{array}$ & IV & 54 & 64 & 69 & 74 \\
\hline Scrub/Brush & $\mathrm{V}$ & 59 & 69 & 74 & 79 & $\begin{array}{l}\text { Forest } \\
\text { deciduous }\end{array}$ & V & 59 & 69 & 74 & 79 \\
\hline Scrub/Brush & VI & 64 & 74 & 79 & 84 & $\begin{array}{l}\text { Forest } \\
\text { deciduous }\end{array}$ & VI & 64 & 74 & 79 & 84 \\
\hline Scrub/Brush & VII & 69 & 79 & 84 & 89 & $\begin{array}{l}\text { Forest } \\
\text { deciduous }\end{array}$ & VII & 69 & 79 & 84 & 89 \\
\hline Scrub/Brush & VIII & 74 & 84 & 89 & 94 & $\begin{array}{l}\text { Forest } \\
\text { deciduous }\end{array}$ & VIII & 74 & 84 & 89 & 94 \\
\hline Scrub/Brush & $\begin{array}{l}\text { Y (Built-up } \\
\text { Area) }\end{array}$ & 54 & 70 & 80 & 85 & $\begin{array}{l}\begin{array}{l}\text { Forest } \\
\text { deciduous }\end{array} \\
\end{array}$ & $\begin{array}{l}\text { Y (Built-up } \\
\text { Area) }\end{array}$ & 54 & 64 & 69 & 74 \\
\hline Grassland & Empty & 51 & 61 & 66 & 70 & $\begin{array}{l}\text { Forest } \\
\text { evergreen }\end{array}$ & Empty & 74 & 84 & 89 & 94 \\
\hline Grassland & Lake & 100 & 100 & 100 & 100 & $\begin{array}{l}\text { Forest } \\
\text { evergreen }\end{array}$ & Lake & 100 & 100 & 100 & 100 \\
\hline Wetland & III & 100 & 100 & 100 & 100 & Built-up area & III & 54 & 65 & 70 & 76 \\
\hline Wetland & IV & 100 & 100 & 100 & 100 & Built-up area & IV & 59 & 70 & 76 & 87 \\
\hline Wetland & $\begin{array}{l}\text { Y (Built-up } \\
\text { Area) }\end{array}$ & 100 & 100 & 100 & 100 & Built-up area & $\begin{array}{l}\text { Y (Built-up } \\
\text { Area) }\end{array}$ & 59 & 70 & 76 & 87 \\
\hline Cropland & $\begin{array}{l}\text { Y (Built-up } \\
\text { Area) }\end{array}$ & 23 & 45 & 58 & 73 & Water & Empty & 100 & 100 & 100 & 100 \\
\hline
\end{tabular}

\section{RESULTS}

The focus of this research is to understand the effect of the land use change on the hydrologic structure of the Terkos Basin in Istanbul Metropolitan Area. Between 1995 and 2010 years, the change of builtup areas is the centre of attention. Land use changes between 1995 and 2010 are summarized in Table 6 and Table 7. 
Geymen / Anadolu Univ. J. of Sci. and Technology - A - Appl. Sci. and Eng. 17 (3) - 2016

Table 6. Land use classification and changes (ha) between 1995 and 2010

\begin{tabular}{|c|c|c|c|c|c|}
\hline Years & Barren Ground & Cropland & Forest & Built-up Area & Water \\
\hline 1995 & 962 & 14448 & 54509 & 340 & 3295 \\
2005 & 783 & 7526 & 61037 & 430 & 3778 \\
2010 & 702 & 7102 & 61376 & 594 & 3780 \\
\hline
\end{tabular}

Table 7. Change in Terkos Basin settlement rates from 1995 to 2010

\begin{tabular}{|c|l|c|r|c|c|c|}
\hline \multirow{2}{*}{$\begin{array}{c}\text { Basin } \\
\text { Code }\end{array}$} & \multicolumn{3}{|c|}{ Basin } & \multicolumn{4}{c|}{ Landsat TM } \\
\cline { 2 - 7 } & \multirow{2}{*}{ Name } & \multirow{2}{*}{ Area } & \multicolumn{3}{c|}{ Built-up Area (ha) } & Change (ha) \\
\cline { 4 - 7 } & & 73539 & 340 & 430 & 594 & $1995-2010$ \\
\hline \hline 5 & Terkos & 73905 & 2010 & 254 \\
\hline
\end{tabular}

\subsection{Curve Number Estimation for Terkos Basin}

The Curve Number estimation process for Terkos Basin is presented in Figures 3-8 and Table 5. Figure 6 is prepared to present Terkos watershed hydrologic soil classification (HST). All geological top layer information categories (Table 5) of the basin are reduced into 4 different HST categories (A, $\mathrm{B}, \mathrm{C}, \mathrm{D})$. Then, the agricultural land use capability class information (I-VIII) is presented in Figure 7. Later, the processed satellite images (1995-2010 Landsat TM) provides the land use information of the basin in 6 different categories. The following steps are completed in the ArcGIS environment. An interface has been developed in ArcGIS 10 environment, which provides the users an efficient and correct CN calculation tool. The tool was developed with Visual Basic Script on an ArcGIS 10. This tool is composed of three parts. These parts are clipping tool, union tools, and curve number database. The tool reduced processing time layers were dissolved before union. Finally, Figure 3-7 are put into an overlay operation, and Figure 8 is obtained. Figure 8 is made up of large number of polygons that each one carries a unique set of information having corresponding HST, ALUC, and LU information (i.e. $\mathrm{g}_{\mathrm{r}}, \mathrm{t}_{\mathrm{Z}}, \mathrm{l}_{\mathrm{k}}$ ) leading to a $\mathrm{CN}$ presented in Table 5 . For each legend color category of Figure 8 , associated $\mathrm{g}_{\mathrm{r}}, \mathrm{t}_{\mathrm{z}}$, and $\mathrm{l}_{\mathrm{k}}$ information, their corresponding $\mathrm{cn}_{\mathrm{xn}}$ number as a function of them $\left(\mathrm{g}_{\mathrm{r}}, \mathrm{t}_{\mathrm{z}}, \mathrm{l}_{\mathrm{k}}\right)$ and associated areal coverage are combined. Finally, the area weighted ( $w \times n n=a x n / \Sigma N n=1$ axn) unique average curve numbers $(\mathrm{CN}=\Sigma \mathrm{Nn}=1 \mathrm{wxnENxn})$ are computed as 59, 61 and 65 respectively 1995, 2005 and 2010 for the Terkos Basin.

\section{CONCLUSION AND DISCUSSION}

In this study, the remote sensing and GIS techniques and the SCS-CN technique were applied to the Terkos Basin. The comparison of the land use/cover types of the three images of 1995, 2005 and 2010, indicated that the area of the cropland and barren ground have decreased in Table 6. But the surface area of the built up areas have increased about 340, 430 and 594 hectares respectively in Table 6 and 7. It seems that most of the land use/cover change has happened into the built up areas due to the increase in the population of the Basin. The increasing of urban area and the decreasing of agricultural land caused the increasing of $\mathrm{CN}$. These land use change will effect precipitation change on direct surface runoff in water basin. The results from curve number method showed an increase in the surface runoff from $59 \%$ to $65 \%$ in 1995 and 2010 respectively. In this period, the main land use changes are due to an increase of urban area, while cropland and barren decreased. The increasing of urban area and the decreasing of agricultural land caused the increasing of $\mathrm{CN}$. These findings, concludes the fact that the increase of surface runoff and decrease of river flows are associated with land use change. The method will provide a better understanding of the main reasons for the effects and will support city administrators in similar projects. The comparison of the change in the land use 
Geymen / Anadolu Univ. J. of Sci. and Technology - A - Appl. Sci. and Eng. 17 (3) - 2016

types highlighted this point that the land use is much more important to the natural resources management. It is highly recommended that the natural resources managers and planners should take this finding into consideration and prevent the increasing destruction of the land sources.

\section{ACKNOWLEDGEMENT}

I would like to thank for the United States Geological Survey (USGS) for supplying data.

\section{REFERENCES}

[1] Stonestrom DA, Scanlon BR and Zhang L. Introduction to special section on Impacts of Land Use Change on Water Resources. Water Resour. Res., 2009; 45, W00A00,doi:10.1029/2009WR007937.

[2] Kim DK, Jeong KS, Do Y, Kim HW, Joo GJ. Assessment of stream integrity in relation to neighboring land use coverage. Ekoloji, 2015; 24 (96):1-12.

[3] Wagner PD, Kumar S, Schneider K. An assessment of land use change impacts on the water resources of the Mula and Mutha Rivers catchment upstream of Pune, India. Hydrol. Earth Syst. Sci., 2013; 17, 2233-2246, doi:10.5194/hess-17-2233.

[4] Miller SN, Kepner WG, Mehaffey MH, Hernandez M, Miller RC, Goodrich DC, Devonald KK, Heggem DT and Miller WP. Integrating landscape assessment and hydrologic modeling for land cover change analysis. J. Am. Water Resour. As., 2002; 38, 915-929.

[5] Seeber C, Hartmann H, Xiang W and King L. Land use change and causes in the Xiangxi catchment, Three Gorges Area derived from multispectral data. J. Earth Sci., 2010; 21, 846-855.

[6] Hansen M, DeFries R, Townshend JRG and Sohlberg R. UMD global land cover classification, Department of Geography, University of Maryland, College Park, Maryland, 1998.

[7] Jensen JR. Remote Sensing of the Environment: An earth resource perspective, 2nd Edn., Pearson Prentice Hall, Upper Saddle River, New Jersey, 2007.

[8] Ghaffari G, Keesstra S, Ghodousi J and Ahmadi H. SWAT simulated hydrological impact of landuse change in the Zanjanrood basin, Northwest Iran. Hydrol. Process, 2010; 24, 892-903.

[9] Im S, Kim H, Kim C and Jang C. Assessing the impacts of land use changes on watershed hydrology using MIKE SHE. Environ. Geol., 2009; 57, 231-239.

[10] Li Z, Liu W, Zhang X and Zheng F. Impacts of land use change and climate variability on hydrology in an agricultural catchment on the Loess Plateau of China. J. Hydrol., 2009; 377, 35-42.

[11] Gul O, Onmus O, S1k1 M. Significant impacts of the water level and human intervention on the natural habitats and breeding water birds in Marmara Lake. Ekoloji 2013; 22(89):29-39.

[12] Bai J. Estimation of the isoprene emission from the Inner Mongolia grassland. Atmospheric Pollution Research, 2015; 3, 406-414, doi: 10.5094/APR.2015.045.

[13] Walna B. Human impact on atmospheric precipitation in a protected area in Western Poland. Results of long-term observations: Concentrations, deposition and trends. Atmospheric Pollution Research, 2015; .5, 778-787, doi: 10.5094/APR.2015.086. 
[14] Klöcking B and Haberlandt U. Impact of land use changes on water dynamics - a case study in temperate meso and macroscale river basins. Phys. Chem. Earth, 2002; 27, 619-629.

[15] Barthel R, Reichenau TG, Krimly T, Dabbert S, Schneider K, Hennicker R and Mauser W. Integrated modeling of global change impacts on agriculture and groundwater resources. Water Resour. Manag., 2012; 26, 1929-1951.

[16] Wijesekara GN, Gupta A, Valeo C, Hasbani J-G, Qiao Y, Delaney P and Marceau DJ. Assessing the impact of future land-use changes on hydrological processes in the Elbow River watershed in southern Alberta, Canada. J. Hydrol., 2012; 412-413, 220-232.

[17] Legesse D, Vallet-Coulomb C and Gasse F. Hydrological response of a catchment to climate and land use changes in Tropical Africa: case study South Central Ethiopia. J. Hydrol., 2003; 275, 67-85.

[18] Mango LM, Melesse AM, McClain ME, Gann D and Setegn SG. Land use and climate change impacts on the hydrology of the upper Mara River Basin, Kenya: results of a modeling study to support better resource management, Hydrol. Earth Syst. Sci., 2011; 15, 2245-2258, doi:10.5194/hess$15-2245$.

[19] Nagy C, Lockaby BG., Helms B, Kalin L, Stoeckel D. Water resources and land use and cover in a humid region: the Southeastern United States. J. Environ. Qual. 2011; 40: 867-878.

[20] Kubat, A., Kaya, H., Güler, G., Sari, F., Özer, O. The effects of proposed bridges on urban macro form of Istanbul: A Syntactic evaluation, 6th Space Syntax Symposium Organizing Committee, ITU, Istanbul, 2007.

[21]. Geymen, A. Impacts of Bosporus Bridges on the Istanbul Metropolitan settlement areas. Land Degradation \& Development, 2013; 24, 10.1002/ldr.1114, 156-169.

[22] Sunar F. An analysis of changes in a multi-date data set: A case study in the Ikitelli Area Istanbul. International Journal of Remote Sensing, 1998; 19(2), 225-235.

[23] Maktav M, Erbek F. Analysis of urban growth using multi-temporal satellite data in Istanbul, Turkey. International Journal of Remote Sensing, 2005; 26(4), 797-810.

[24] Musaoglu N, Tanik A, Kocabas V. Identification of land-cover changes through image. Processing and associated impacts on water reservoir conditions. Environmental Management, 35(2), 220-230, 2005.

[25] Kaya S, Curan PJ. Monitoring urban growth on the European Side of the Istanbul Metropolitan Area: A case study, International Journal of Applied Earth Observation and Geoinformation, 2006; 8, $18-25$.

[26] Goksel C. Monitoring of a water basin area in Istanbul using remote sensing data. Water Science and Management,1998; 38(11): 209-216.

[27] Kucukmehmetoglu M, Geymen A. Measuring the spatial impacts of urbanization on the surface water resource basins in Istanbul via remote sensing. Environmental Monitoring and Assessment, 2008.

[28] Erdas, Erdas field guide Erdas, Fifth edition, Atlanta, Georgia, 1999. 
Geymen / Anadolu Univ. J. of Sci. and Technology - A - Appl. Sci. and Eng. 17 (3) - 2016

[29] Esri, Using ArcGIS Desktop. ESRI Press publishes: Redlands, California, 2008.

[30] Jenness J, Wynne JJ. Cohen's Kappa and classification table metrics 2.0: An ArcView 3x Extension for accuracy assessment of spatially explicit models, Southwest Biological Science Center, Open-File Report of 2005-1363, Flagstaff, 2005.

[31] Congalton RG. A review of assessing the accuracy of classifications of remotely sensed data. Remote Sensing of Environment, 1991; 37, 35-46.

[32] Bedien PB, Huber WC. Hydrology and floodplain analysis. Upper Saddle River, N.J.: Prentice Hall, 2002.

[33] Chow VT, Maidment DR, Mays LW. Applied Hydrology. New York: McGraw-Hill, Inc. 1988.

[34] Şen Z. Spatial Modeling Principles in Earth Sciences. Springer Verlag, 351 pp, 2009. 